\title{
Az örök falu - hanyatlás és fennmaradás. A községi népesség számának változása
}

\author{
The eternal village - decline and survival. The change in the \\ population of the villages
}

\author{
BALOGH KAROLINA, KOVÁCH IMRE
}

\begin{abstract}
BALOGH Karolina: tudományos segédmunkatárs, Társadalomtudományi Kutatóközpont, Szociológiai Intézet; 1097 Budapest, Tóth Kálmán u.4.; balogh.karolina@tk.hu; https://orcid.org/0000-0002-2487-1332

KOVÁCH Imre: kutatóprofesszor, Társadalomtudományi Kutatóközpont, Szociológiai Intézet; 1097 Budapest, Tóth Kálmán u.4.; egyetemi tanár, Debreceni Egyetem, Politikatudományi és Szociológiai Intézet; 4032 Debrecen, Egyetem tér 1.; kovach.imre@tk.hu; https://orcid.org/0000-0002-3966-1274
\end{abstract}

KULCSSZAVAK: községek népességszáma; népességdinamika; vándorlás; demográfia

ABSZTRAKT: A tanulmány célja a községi népességszám változásának elemzése a rendszerváltozástól 2016-ig terjedő időszakban. A kutatás céljának megvalósításához új települési szintű adatbázisba rendeztük a KSH és a TEIR adatait. Az elemzés a községi népesség abszolút számának alakulását, valamint a változatlan közigazgatási besorolású községek adatait is magában foglalja, valamint röviden bemutatja a városi státuszt elnyerő települések népességének változását is. Tanulmányunk a települések, és ezek közül a falvak népességváltozásának hosszú időtartamú trendjeiről szól, és bemutatja az 1995 és 2016 között mindvégig községi státuszú települések vándorlási és demográfiai folyamatait, a népességdinamikai változásokat, a települések fejlettségi dimenzióinak és a népességszám változásának összefüggéseit. A tanulmány alapjául szolgáló elemzések rámutatnak az abszolút községi népességszám nagymértékủ csökkenésére, ugyanakkor a községi besorolású települések népességének nagyfokú stabilitására is. Tanulmányunk elemzi a népesség szerinti faluosztályok között végbemenő erőteljes vándorlási folyamatokat, valamint a vándorlás hátterében álló legfontosabb motiváló erőket is.

A falvak legnagyobb népességvesztése a 152 várossá nyilvánítás következménye. A folyamatosan községi besorolású falvak népességének a csökkenése csak három százalék körüli, ugyanakkor a „község” kategóriához tartozó települések között jelentős vándorlás történt. A kisfalvak lakossága gyorsuló ütemben csökken, a nagyobb falvakba vándorol, és ez a folyamat mind a nagyobb községek, mind az aprófalvak társadalmának szerkezetét és életesélyeit átalakítja.

Karolina BALOGH: junior research fellow, Institute for Sociology, Centre for Social Sciences; Tóth Kálmán u. 4., H-1097 Budapest, Hungary; balogh.karolina@tk.hu; https://orcid.org/00000002-2487-1332

Imre KOVÁCH: research professor, Institute for Sociology, Centre for Social Sciences; Tóth Kálmán u. 4., H-1097 Budapest, Hungary; professor, Department of Sociology and Social Policy, University of Debrecen;Egyetem tér 1., H-4032 Debrecen, Hungary; kovach.imre@tk.hu; https:// orcid.org/0000-0002-3966-1274

KEYWORDS: population of villages; population dynamics; migration; demography

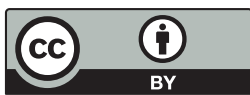


ABSTRACT: The aim of the study is to analyse change in the population of villages in the period from 1995 to 2016. We organized the data of the Central Statistical office (CSO) and the Land Information System (LIS) into a new database for the purposes of the research. The analysis discusses reasons for the decline in the absolute population number of the rural population and presents the population impact of the transition of 152 larger villages to urban administrative status. Some of the new rural towns, mainly in metropolitan agglomerations, may have seen an increase in population, but in nearly half of the new towns the new administrative rank could not stop population decline.

The article first presents long-term trends in population change between settlements (villages, towns, regional centres, capital). The following section discusses migration and demographic processes of the villages, changes in population dynamics, the relationships between the development level of the settlements and migration. According to the indicator of population dynamics, more than one third of the municipalities belong to the fully decreasing category from year to year, while the proportion of growing municipalities varies around 10 percent.

The study shows a large decrease in the absolute population number of villages, but at the same time a relative stability of the population of villages with unchanged administrative status, which results in a rearrangement of population processes between smaller and larger villages. The population of villages with the same administrative classification was relatively stable over 20 years. The loss of the total rural population was barely three percent. In contrast, there has been a remarkable population change between village categories in terms of population size. A substantial proportion of the inhabitants of hamlets does not migrate to cities but to larger villages and this migration leads to significant structural, demographic changes and distortions in the society of both types of rural settlements.

\section{Bevezetés}

A közvéleményben és a tudományos elemzésekben elsősorban a falvak évtizedes trendek szerinti folyamatos népességcsökkenése kapott figyelmet, ami érthető is, mert a falusi lakosság 700000 körüli fóvel lett kevesebb 1990 után (Kovách, Megyesi 2018). Az összetettebb és több adatbázisra is kiterjedő elemzés azonban pontosabb eredményre vezethet, és követhetőbbé teheti a falvakban zajló népességváltozás irányait. A kisfalvak népességszáma valóban gyorsan csökken, de a községek egészében már jóval kiegyenlítettebb a népesség vándorlásának és demográfiai változásának a mérlege. A kisfalvak népességét elsősorban a nagyobb községek fogadják be, a falvak lakosságának a sokszázezres csökkenése pedig leginkább a 152 település várossá nyilvánításának következménye, ami ugyanakkor alig változtat a települési környezet minőségén. Tulajdonképpen nehezen lehet megfelelő rendezettségü adatokat találni a falusi népességváltozás valóságos mértékének trendjeire vonatkozóan. Talán ez is az oka annak, hogy kevéssé ismert és tudatosult az a tény, hogy az 1990-et követő évtizedekben végig község besorolású települések népességének (2,89 millió fö 2016-ban) csökkenése összeségében csekély 100000 (3-3,5 \%) fö alatti volt. A tanulmányunk címében szereplo „örök falu” kifejezés éppen ezt hangsúlyozza. Munkánk célja az volt, hogy az alapadatokból indulva, néhány új szempont és összetettebb módszer felhasználásával bővítsük a falusi népességszám változásáról való ismereteket.

A hosszú időtartamú trendek elemzése alapján Németh és Dövényi (2016) arra a következtetésre jut, hogy egyre inkább a vándorlás határozza meg a tele- 
pülések (városok és községek) népességszámának alakulását. A községek abszolút népességszám-változásának évtizedes tendenciáihoz az elvándorlás (Dövényi 2009; Bálint 2012; Gödri, Spéder 2009; Németh, Dövényi 2016), kisebb mértékben a természetes fogyás (Kulcsár, Obádovics 2016; Bálint, Obádovics 2018), valamint a várossá nyilvánítások emelkedő száma és a teljes magyar lakosság csökkenése (Szepesi 2008; Kovách, Megyesi 2018; Csurgó et al. 2018) egyaránt hozzájárult.

A falusiak aránya a teljes magyar népességen belül a számszerü csökkenés ellenére egyharmad körüli, ami Közép-Kelet-Európában nem szokatlan, de a 2004 előtti Európai Unió átlagához hasonlítva a magasabbak közé tartozik (Csatári 2004; Kovách 2012). A községi népesség változásával kapcsolatban fontos megjegyeznünk, hogy bár a községi/falusi és a vidéki fogalmai között van átfedés, de a „vidéki” értelmezése körül mind a nemzetközi, mind a magyar irodalomban nagy a bizonytalanság (Csatári 2007; Kovách 2012; Kulcsár 2017). Egy új kutatás a községben és a kisvárosokban élőket egyaránt vidékinek tekinti és arányukat a magyar társadalmon belül 54 százalékban állapítja meg (Balogh et al. 2020). Ez az adat ismételten arra figyelmeztet, hogy a statisztikai/közigazgatási kategóriákat a népességmozgások értékelésénél érdemes körültekintéssel használni, mert például a nagyobb községekből a kisvárosokba elvándorlók nem feltétlenül kerülnek gyökeresen különböző életfeltételek közé.

Az EU országainak többségében a rurális térségekben élők aránya a belső migráció következtében csökken (Schmied 2002; Solana-Solana 2010), ami a hazainál sokkal árnyaltabb tematikájú vándorlás- és migrációkutatásokat ösztönzött (Boyle, Halfacree, 1998, 2014; Scott et al. 2017). A nemzetközi szakirodalomban a vidéki térségben élők vándorlásának az okai között a strukturális tényezőket (foglalkozási szerkezetet, jövedelemstruktúrát, munkaerőpiacot, iskolarendszert, infrastruktúrát, az életmód anyagi mutatóit és az értékeket szokás megkülönböztetni. Stockdale (2002) azt emeli ki, hogy a migrációra vállalkozókat gyakran összetett hatások motiválják, amelyek között a racionális megfontolások, ugyanakkor a helyi kötődés, a vidéki idill képzete, a családi és egyéb kapcsolatrendszer nyújtotta biztonság (Callela 1986; Allston 2004; Thissen et al. 2016), a nemi hovatartozás (Leibert 2016) és a vidék megváltozott percepciója (Farrel et al. 2011) egyaránt fontos szerepet játszhatnak.

Kutatásunk fö kérdése, hogy miként írható le a községek népességének változása 1995 és 2016 között, s hogy a változás milyen tendenciákkal jellemezhető. Különösen arra vagyunk kíváncsiak, hogy mit lehet elmondani az 1995 és 2016 között változatlan közigazgatási besorolású községek népesedési folyamatairól. A tanulmány újdonsága, hogy a hozzáférhető legújabb adatokkal 2016-ig egészíti ki a községi népességszám változásának bemutatását, és nem csupán az abszolút számok alapján, hanem az összes településhez hasonlított relatív mutatókkal is. A népességdinamikai változások módszerének alkalmazásával is elemezzük az összetett népesedési folyamatokat, és kísérletet teszünk a települések fejlettségi mutatói valamint a népességszám-változás összefüggéseinek értelmezésére. 


\section{Adatok, módszertani megjegyzések}

A községek népességszám-változásának elemzéséhez kialakított adatbázis az 1990 és 2016 közötti adatokat településsorosan tartalmazza. A települések jogállása minden évnél az adott időszakban érvényes besorolás szerint szerepel, ami így lehetővé teszi a településszerkezet változásainak a kiszürését, így például a várossá nyilvánítások alakulását 1990 és 2016 között. Elemzésünk során e dinamikus változás nyomon követhetőségét elengedhetetlennek tartottuk, mert a közigazgatási besorolás megváltoztatása jelentős nehézségeket eredményezhet pl. a népességadatok idősoros értelmezésében. A tudományos elemzések általánosan bevett gyakorlata, hogy a vizsgált időszak utolsó éve szerinti ${ }^{1}$ közigazgatási besorolást vonatkoztatják az összes évre, az adatok homogenitása és az idősoros összehasonlíthatóság érdekében. Ez helyes eljárás egy adott tanulmány szempontjából, ugyanakkor azt eredményezheti, hogy különböző években készített elemzésekben sok esetben nem azonos a „községek” kategóriába tartozó települések csoportja. Az ilyen hosszú időintervallumra vonatkozó elemzésben, mint amire vállalkoztunk, reflektálnunk kellett erre a módszertani kihívásra. A tanulmányban ezért bemutatjuk a községi népesség változásának abszolút számait, azaz azt, hogy mekkora volt az egyes időpontokban és hogyan változott a községi besorolású települések lakossága, illetve azt, hogy az 1990 után mindvégig község besorolású települések népességszáma miként alakult. A harmadik fejezetben az abszolút számokat, az adott időpontban községi besorolású településeken élők népességszámát használjuk, míg az elemzés további részei és megállapításai (népesség alakulása, népességdinamika, vándorlás) a változatlan közigazgatási besorolású községekre ${ }^{2}$ vonatkoznak. Az adatbázis változói a népességváltozás összetevőit mérik: az adott tárgyévben a településen születettek és meghaltak számát, illetve az oda- és az onnan elvándorlók adatait.

Az adatbázis felépítése a TEIR ${ }^{3}$ települési adatai és a KSH egyedi adatszolgáltatása alapján történt. A TEIR adatbázisban nyilvánosan elérhetőek voltak a belföldi vándorlás, illetve az év végi lakónépesség adatai. Az egyéb népesedési folyamatokra vonatkozó adatokat (születések és halálozások száma, nemzetközi vándorlásban résztvevők száma) a KSH-tól kaptuk meg. Az adatokat a településkód és az évszám alapján kapcsoltuk össze. ${ }^{4} \mathrm{~A}$ TEIR-ből letöltött települési szintü adatokat országos szintre aggregálva vetettük össze a KSH honlapján elérhető országos adatokkal, így ellenőriztük azok minőségét.

Az adatbázis kialakítása jelentős, néhány elemében kritikai munkát igényelt. A létrehozott adatbázis 1990-ig visszamenőleg tartalmaz adatokat, az elemzésben mégis leginkább 1995-től kezdődően használjuk azokat. Ennek egyik oka az, hogy a KSH oldalán elérhető országos népességadatok 1994-ig nem egyeznek meg a TEIR adatokkal, valamint az, hogy a belföldi vándorlásra vonatkozó adatok csak 1995-től kezdődően érhetőek el a KSH oldalán, s ezért nem volt módunk a 19901994 közötti adatok ellenőrzésére. Tisztában vagyunk azzal, hogy már a korai ki- 
lencvenes években megindult mind a falusi, mind a városi társadalom települések közötti vándorlásokra is ható drámai átrendeződése, de a hozzáférhető adatok minősége miatt mégis 1995-öt választottuk a kiinduló évnek.

A belföldi vándorlásra vonatkozó adatok ${ }^{5}$ értelmezését nehezítheti az állandó és az ideiglenes vándorlás fogalmainak változó használata. A hazai tanulmányok is eltérő gyakorlat szerint alkalmazzák ezeket a kategóriákat. Van, amikor az ideiglenes és az állandó vándorlást együttesen számítják (Dövényi 2007, 2009), van, amikor egymástól megkülönböztetve (Gödri, Spéder 2009; Bálint 2011), és van, amikor csak az állandó vándorlást veszik figyelembe (Bálint, Gödri 2015; Bálint, Obádovics 2018). Ennek oka az, hogy a lakcímbejelentési rendszer alapján megkülönböztethető, ha valaki a településhatárt átlépve megváltoztatja a lakóhelyét, ami állandó vándorlásnak számít, vagy lakóhelyét fenntartva változtat lakást, s az új lakást tartózkodási helyként jelöli meg, ami ideiglenes vándorlásként szerepel az irodalomban. Az ideiglenes vándorlások számbavétele azonban módszertani korlátokba ütközik, mert ezek nagy része látenciában marad, hiszen sok esetben a lakóhelyüktől ideiglenesen távol élők nem jelentik be tartózkodási helyüket, így az nem jelenik meg a lakcímnyilvántartási rendszerben.

A másik módszertani probléma az ideiglenes vándorlások számbavételével kapcsolatos, és adminisztratív okokra vezethető vissza; az ideiglenes vándorlások számában ugyanis azok is szerepelnek, akik a törvényi előírások ellenére nem hosszabbították meg határidőn belül tartózkodási helyük regisztrációját, így (ideiglenes) visszavándorlónak minősülnek. Az idősoros adatok értelmezésében további nehézséget okoz, hogy a törvényi határidő 2006-ban megváltozott, és időtartama két évről öt évre nőtt, s ennek hatása a 2008-as adatokban érvényesül is, ugyanis a vándorlások számában visszaesés tapasztalható. Az ideiglenes vándorlás mérésének módszertani akadályai miatt sok szerző a megbízhatóbbnak tartott, állandó vándorlásra vonatkozó adatokkal dolgozik. A tanulmányban a vándorlások együttes számbavételét használjuk, melynek kettős oka van. Egyrészt ez az adat állt rendelkezésünkre hosszabb idősorként, másrészt a községek népességváltozásának tipizálásához a vándorlások együttes figyelembevételével jobban megbecsülhető, hogy egy település inkább kibocsátó, vagy célterület.

A nemzetközi vándorlásra vonatkozó adatokhoz (bevándorló külföldiek száma és külföldre vándorló magyarok száma) a KSH egyedi adatközlése révén jutottunk hozzá, ezeket az adatokat azonban visszamenőleg csak 2000-ig tudták a rendelkezésünkre bocsátani, ami korlátozta a felhasználásukat.

Elsősorban a 2006-2016 közötti időszak vizsgálatára törekszünk, hiszen a megelőző, alapos és részletesebb elemzések a 1990-2011 közötti időszakra vonatkoztak (Dövényi 2007, 2009; Kulcsár, Obádovics 2016), így mi a legtöbb esetben az utolsó rendelkezésünkre álló év adatait megelőző tízéves időszakot vesszük figyelembe, egyes esetben pedig a hosszú idősoros adatokat is bemutatjuk. 


\section{A népesség számának változása a településkategóriák szerint}

Ebben a fejezetben a községi népesség abszolút számának alakulását mutatjuk be. Az ország lakossága az év végi népességadatok szerint az 1995-ös 10212300 főről 2016 végére 9797561 före csökkent. Ebben az időszakban az ország településeinek (községek és városok együtt) száma pedig 3 125-ről 3 155-re nőtt. A községek népességszáma 2016-ra 2894854 före csökkent. Ebben az időszakban a községek száma 2 931-ről 2 809-re esett a közigazgatási változások miatt. A 21 év alatt 152 községet nyilvánítottak várossá.

A községek népességének csökkenése folyamatos, de figyelemre méltó egybeesés, hogy a főváros, megyei jogú város, város, község felosztásban a falvak 2009-ben szorultak vissza a második helyre a népesség nagysága szerint, amikor a pénzügyi és a gazdasági válság hatása a legerősebb volt (1.ábra).

A teljes magyar népesség csökkenésének következtében a települések közel hetven százaléka veszített a lakosságából. Budapest és a 23 megyei jogú város közül 18, az egyéb városok kb. kétharmada, míg a falvak $70 \%$-a is ezen a listán van. A községek 12\%-ában stagnál a népesség száma. Az 586 növekvő népességü település között 509 a községek száma, a 73 növekvő népességű város közül 53-at 1995 után nyilvánítottak várossá.

Dolgozatunk elején utaltunk rá, hogy ugyan a község és vidék fogalmai között nagy az átfedés, de különösen a vidék értelmezési bizonytalanságai miatt a

1. ábra: A népességszám változása 1995 és 2016 között településtípusonként (az adott évi besorolás szerint)

Population change between 1995 and 2016 by type of the settlement

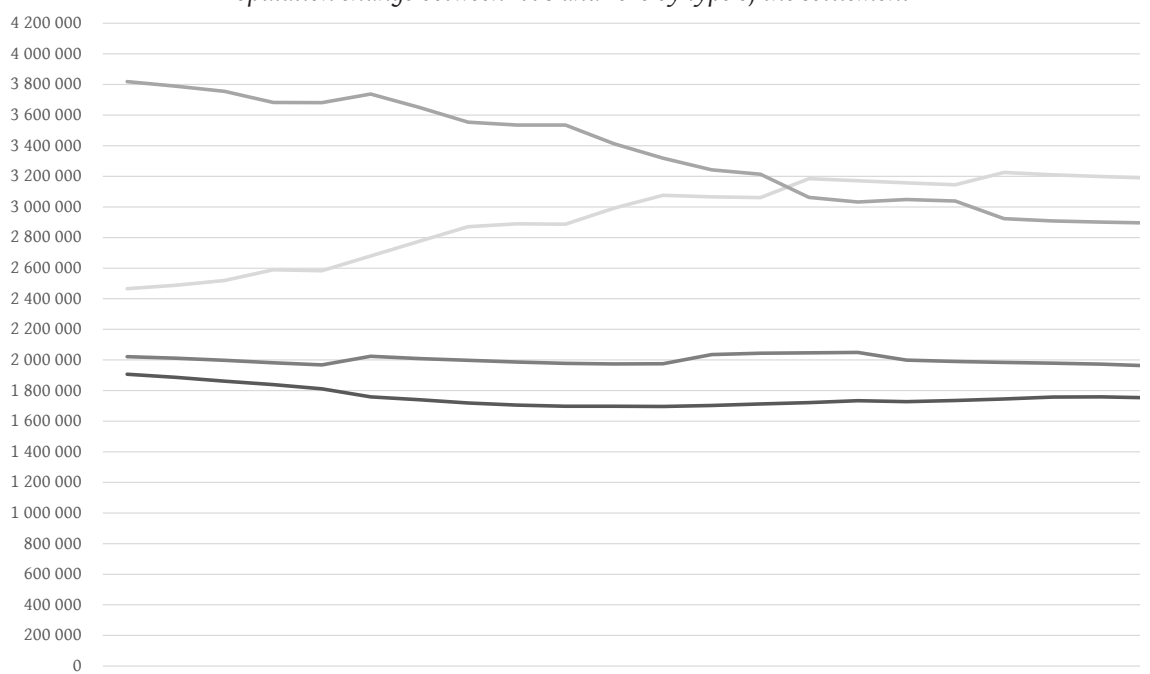

$19951996199719981999200020012002200320042005200620072008 \quad 2009201020112012201320142015 \quad 2$

Forrás: TEIR adatok alapján saját szerkesztés 
községek népességét nem lehet kizárólagosan és mereven a vidéki népességgel azonosítani. Az új városokkal foglalkozó irodalom határozottan figyelmeztet arra, hogy a várossá nyilvánítások mögött kevésbé a minőségi elemek, mint inkább az érdekharcok és a forrásszerzés-függőség áll (Kulcsár, Brown 2010; Trócsányi et al. 2007). Egyáltalán nem biztos, hogy a közigazgatási státusz formális változása rövid időn belül együtt jár a városfunkciók megerősödésével, és különösen nem jelenti a vidékinek tekintett életmódminták feladását (Pirisi 2009). 2000 és 2010 között sokkal több várossá nyilvánítás történt, mint a megelőző évtizedben (Kovách, Megyesi 2018), de megközelítően ugyanilyen arányban nőtt a községek száma is. A 2008 és 2009 közötti falusi népességveszteséget elsősorban az elvándorlás és a természetes fogyás következményének tarthatjuk. Hasonló arányú a csökkenés 2012 és 2013 között, ami a községi népesség szociális juttatásait és munkaerőpiaci esélyeit különösen hátrányosan érintő új társadalom- és szociálpolitikai rendszer bevezetésével járó válság következménye lehet. A községek lakosságvesztése 2014-től évi néhány ezerre csökken, mintegy visszatérve a hosszú időtartamú trendvonalhoz.

A községek népesedési folyamatok miatti népességvesztése a 2 . ábrán követhető nyomon. Jól látszik a természetes fogyás folyamatossága, amely 1995 óta évi 10-15 ezres veszteséget jelent a községekben. A pozitív vándorlási egyenleg 2006-tól kezdődően vált negatívvá. A falvakból történő elköltözés pedig 2008-ban és 2010-ben jelentette a legnagyobb veszteséget.

2. ábra: A községek népességének változása Population change in villages

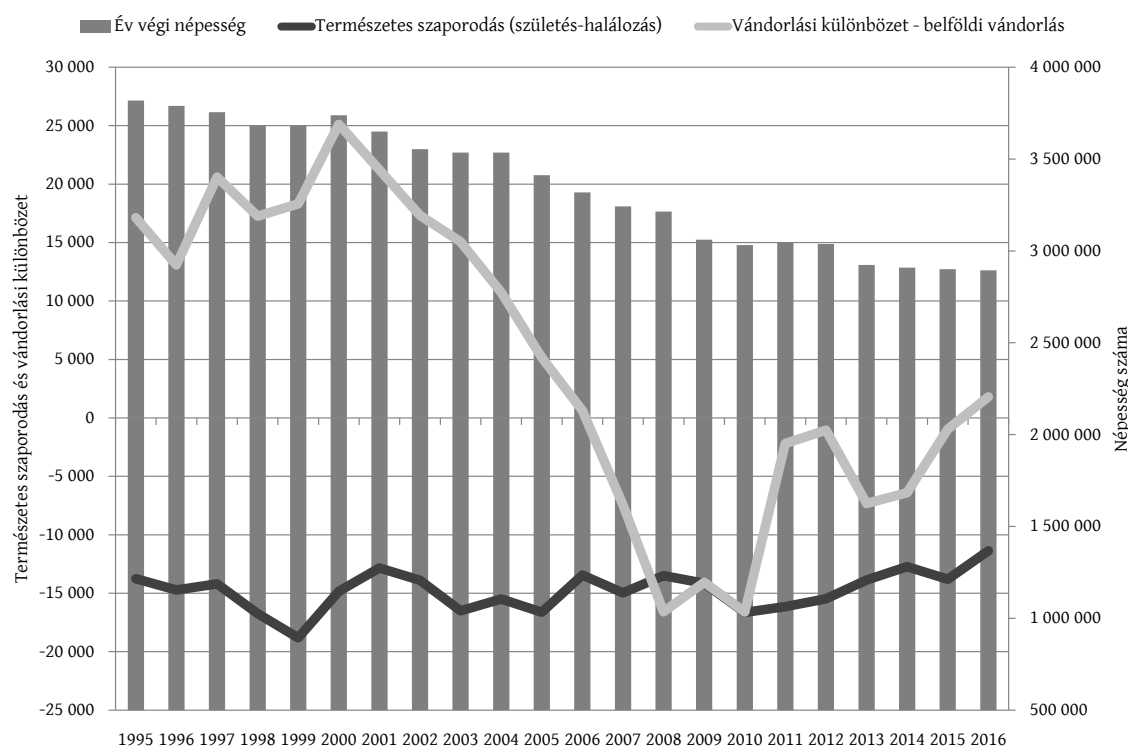

Forrás: TEIR, KSH adatok alapján saját szerkesztés 
Ha ki akarjuk küszöbölni a várossá nyilvánítások miatt bekövetkezett községi népességfogyást, érdemes azoknak a településeknek a népességváltozását elemezni, amelyek közigazgatási besorolása a vizsgált időszakban végig község volt (3. ábra). 1995-ben 846 044-en, míg 2016-ban 938 670-en éltek azokon a településeken, amelyeket a két időpont között várossá nyilvánítottak, ezért a községi népességfogyás elsődleges oka ez az adminisztratív változás (1. sz. melléklet).

3. ábra: Magyarország településeinek közigazgatási besorolása, 2016 Administrative classification of Hungarian settlements, 2016

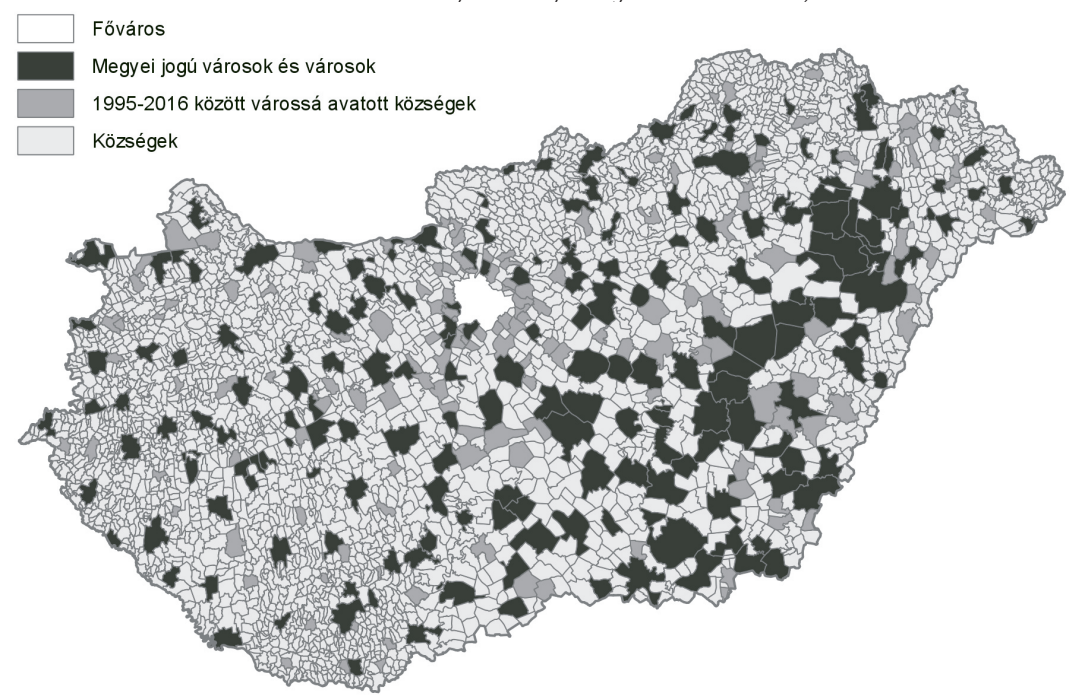

Forrás: TEIR adatok alapján saját szerkesztés

A városi jogállás megszerzése nem feltétlenül változtatott az adott település népesedési folyamatainak irányán. Az 1. táblázat adatai szerint az új városok mintegy harmadában növekvő, míg 44 százaléka esetében csökkenő volt a lakosság száma. A várossá nyilvánítás ez esetek többségében az érintett települések regionális népesedési adottságain sem változtat. Budapest vonzáskörzetének várossá avatott településein folyamatosan nő a lakosságszám, míg az új alföldi kis-

1. táblázat: A várossá nyilvánított községek népességének a változása 1995 és 2016 között Population change of the settlements whose administrative classification changed from village to city between 1995 and 2016

\begin{tabular}{lr}
\multicolumn{1}{c}{ Népességvältozäs kategóriäi } & Települések szäma \\
\hline 1. Növekvő & 53 \\
2. Stagnáló +/- 3 százalék & 25 \\
3. 4-9 százalékos csökkenés & 19 \\
4. 10-19 százalékos csökkenés & 49 \\
5. <= 20 százalékos csökkenés & 6 \\
\hline Összesen & 152 \\
\hline
\end{tabular}


városok népességcsökkenésén, néhány kivételtől eltekintve, a városi státusz megszerzése sem változatott.

A 4. ábrán jól látható, hogy a változatlan közigazgatási besorolású községek népességszáma stabilabb, 1995-ben 2972667 fó, 2016-ban 2894854 fö élt ezekben a falvakban, ami mindössze 78000 fö körüli csökkenést jelent. Ráadásul, 2000 és 2008 között többen éltek ezekben a falvakban, mint 1995-ben. A természetes fogyás és a vándorlási különbözet nem tér el az előzőekben bemutatott trendektől.

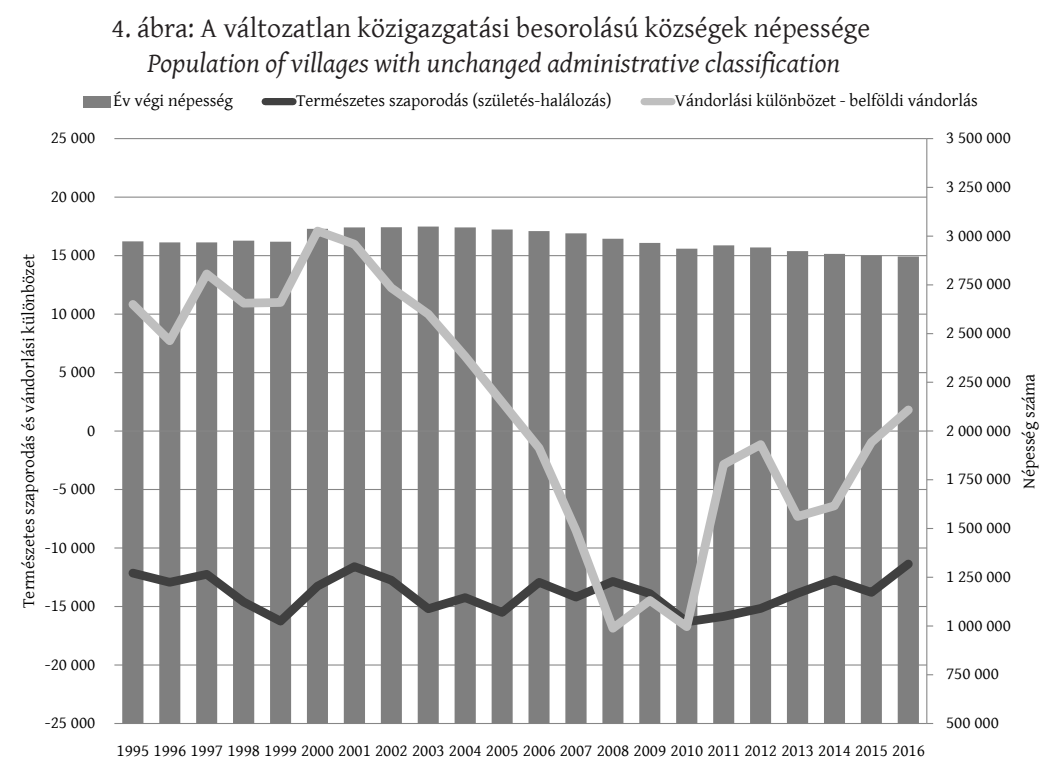

Forrás: TEIR, KSH adatok alapján saját szerkesztés

\section{A változatlan közigazgatási besorolású községek népességének változása és vándorlási trendjei}

A természetes szaporodást felmutató településekből egyre kevesebb van, és kistérségi szinten még rosszabb a helyzet, hiszen egy-egy térségen belül a csekély mértékü természetes szaporodás nem tudja ellensúlyozni a természetes fogyást. A települések népességszámának alakulását elsősorban a vándorlás dönti el: amennyiben ez pozitív, a népességszám növekszik, szinten marad, vagy legrosszabb esetben csak kismértékben csökken (Dövényi 2009). Az ezer före jutó vándorlások mért számának 1994-től növekvő dinamikája 2008-ban csökkenésbe fordult (Statisztikai Tükör 2012), ami feltehetően kapcsolatban van a lakcímbejelentési rendszerben történt adminisztratív változással, amelyről már a módszertani részben szót ejtettünk. A legstabilabb népességszámú községek elsősorban az ország észak-keleti részén, az Alföld középső észak-déli sávjában, a budapesti 
agglomerációt övező térségekben és az észak-nyugat dunántúli területeken helyezkednek el.

A vándorlási egyenleg szerint a vándorlás célterülete elsősorban Közép-Magyarország, illetve a Nyugat-Dunántúl, amely a hosszú idősoros adatok alapján mindig is egy keletről nyugatra irányuló általános vándorlási tendenciát jelent (Gödri, Spéder 2009), azaz a belföldi vándorlás a gazdaságilag elmaradottabb területekről az ország fejlettebb régióiba irányul (5. ábra). A belföldi vándorlásból adódó legnagyobb veszteség Észak-Magyarországot és az Észak-Alföldet érinti (Bálint, Gödri 2015).

Ismert azonban, hogy míg 1990 előtt Budapest kiemelt vándorlási célterületnek számított, a '90-es évek közepétől, a lakásprivatizáció és egy sor strukturális és életmódváltozás következtében megindult az elvándorlás Budapestről, elsősorban a környező agglomerációba. A Budapestről történő kiköltözés a 2000-es évek közepéig mérséklődött, majd 2007-től kezdődően a főváros vándorlási vesztesége megszűnt, a népességnyerés azonban nem állandósult, $\mathrm{s}$ az ezredfordulót követően újra tapasztalható volt a Budapestről történő elköltözés (Statisztikai Tükör 2012; Gödri, Spéder 2009).

A községek népességszámának alakulását nagymértékben befolyásolja a belföldi vándorlás, különösen a Budapestet érintő vándorlási trendek viszonylatában. Az 1990-es években elszenvedett veszteséget nagyrészt Budapest agglo-

5. ábra: A változatlan közigazgatási besorolású községek lakosságszámának a változása 1995-2016 között

Population change of villages with unchanged administrative classification between 1995 and 2016

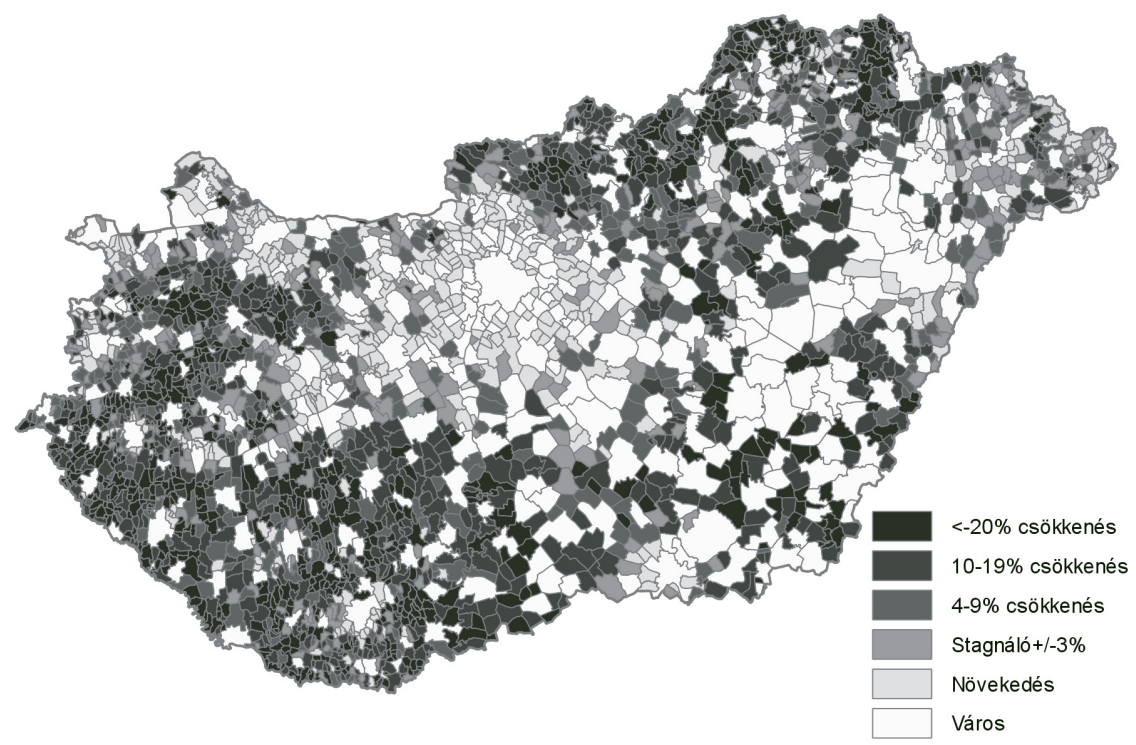

Forrás: TEIR adatok alapján saját szerkesztés 
merációja szívta fel, s így a vándorlási nyereség a községek esetében tapasztalható (szuburbanizáció jelensége), amikor pedig 2007-ben Budapest vándorlási vesztesége megállt, a községekben újra negatívvá vált a vándorlási egyenleg (Gödri, Spéder 2009).

A vándorlási folyamatok által kedvezően érintett területek között elsőként a fóváros agglomerációjához tartozó kistérségeket kell megemlíteni. Előnyös vándorlási egyenleg mutatkozott még néhány Balaton-parti, alapvetően üdülőfunkciót betöltő kistérségben, Észak-Keleten és a nyugati határszélen. Ezzel szemben aktív elvándorlás tapasztalható a kedvezőtlen gazdasági adottságú, alacsony foglalkoztatottsággal, magas munkanélküliséggel sújtott területeken, elsősorban az ország északi, délkeleti és délnyugati térségeiben (Bálint, Gödri 2015). A községek esetében, a budapesti agglomeráció kivételével, a gazdasági alulfejlettség miatt kisebb a bevándorlás, ami további hátrányokat generál. Németh (2008) kutatási eredményei szerint az alacsony státuszú csoportok az átlagon aluli, vagy alacsony státuszú területekre vagy területek között vándorolnak, így az alacsony státuszú területeken kumulálódik az alacsony státuszú népesség.

A népességváltozás mutatói a községek népességszáma szerint (2. táblázat) egyértelmủen jelzik, hogy a legkisebb lélekszámú falvakat fenyegeti a legsúlyosabban a népességcsökkenés. Az 500 fö alatti községek mintegy 80 százaléka tartozik a csökkenő népességü falvak közé, és több mint 50 százalékuk vesztesége meghaladja a 20 százalékot is. Minél nagyobb egy falu népessége, annál kisebb a lakosságcsökkenés tendenciája, ami azt is megmutatja, hogy a községek népességszámának a változása a kisebb és nagyobb falvak közötti népesedési folyamatok átrendeződését is eredményezi. A kisfalvak lakóinak jelentös része nem a városokba, hanem a nagyobb falvakba vándorol. A folyamatosan községi jogállású települések viszonylag stabilabb lakosságszáma mögött (80 000 körüli veszteség 1995 és 2016 között) a falvak közötti drámai átrendeződés zajlik. A kisfalvak gyorsuló ütemben vesztik el a népességüket, ugyanakkor a nagyobb községek többségének népességszáma inkább növekvő tendenciájú. A 23 db 5000 főnél nagyobb község közül 18-nak, a 372 darab 2 000-4 999 fö közötti népességszámú falvak közül 136-nak nő a lakossága (2. táblázat). A növekvő népességü falvak között csak $211 \mathrm{db} 1000$ fö alatti van az összesen 1 769-ből, míg ennek a kategóriának több mint a háromnegyedében (1 395 db) viszont csökken a lakosság.

A vándorlási különbözet vizsgálata is alátámasztja a falvak közötti mobilitást, és a kisfalvak erős vándorlási veszteségét. Ha összesítjük a vándorlási különbözetet évenként 1995 és 2016 között, jól látható, hogy az 1000 fő alatti települések több mint 45000 főt vesztettek el a belföldi vándorlás folyamatai miatt. 
2. táblázat: A népességváltozás típusai a változatlan közigazgatási besorolású községekben népességnagyság szerint, 1995-2016 között

The type of population change in the settlements with unchanged administrative classification by the population size of the settlements between 1995-2016

\begin{tabular}{|c|c|c|c|}
\hline $\begin{array}{l}\text { Település népességének } \\
\text { nagysága (fó) }\end{array}$ & $\begin{array}{c}\text { A népességváltozás } \\
\text { kategóriái }\end{array}$ & $\begin{array}{l}\text { Települések } \\
\text { száma }\end{array}$ & $\begin{array}{c}\text { Települések aránya a népesség- } \\
\text { nagyság kategóriáin belül (\%) }\end{array}$ \\
\hline \multirow{6}{*}{$0-499$} & Növekvő & 105 & 9 \\
\hline & Stagnáló +/- 3 százalék & 77 & 6 , \\
\hline & $\begin{array}{l}4-9 \text { százalékos } \\
\text { csökkenés }\end{array}$ & 111 & 9, \\
\hline & $\begin{array}{l}\text { 10-19 százalékos } \\
\text { csökkenés }\end{array}$ & 236 & 21, \\
\hline & $\begin{array}{l}<=20 \text { százalékos } \\
\text { csökkenés }\end{array}$ & 598 & 53, \\
\hline & Együtt & 1127 & 100, \\
\hline \multirow{6}{*}{$500-999$} & Növekvő & 106 & 16, \\
\hline & Stagnáló +/- 3 százalék & 86 & 13, \\
\hline & $\begin{array}{l}4-9 \text { százalékos } \\
\text { csökkenés }\end{array}$ & 111 & 17, \\
\hline & $\begin{array}{l}\text { 10-19 százalékos } \\
\text { csökkenés }\end{array}$ & 224 & 34, \\
\hline & $\begin{array}{l}<=20 \text { százalékos } \\
\text { csökkenés }\end{array}$ & 115 & 18, \\
\hline & Együtt & 642 & 100, \\
\hline \multirow{6}{*}{$1000-1999$} & Növekvő & 144 & 23 , \\
\hline & Stagnáló +/- 3 százalék & 106 & 17, \\
\hline & $\begin{array}{l}\text { 4-9 százalékos } \\
\text { csökkenés }\end{array}$ & 134 & 21 , \\
\hline & $\begin{array}{l}\text { 10-19 százalékos } \\
\text { csökkenés }\end{array}$ & 176 & 28, \\
\hline & $\begin{array}{l}<=20 \text { százalékos } \\
\text { csökkenés }\end{array}$ & 55 & 8, \\
\hline & Együtt & 615 & 100, \\
\hline \multirow{6}{*}{$2000-4999$} & Növekvö & 136 & 36 , \\
\hline & Stagnáló +/- 3 százalék & 61 & 16, \\
\hline & $\begin{array}{l}4-9 \text { százalékos } \\
\text { csökkenés }\end{array}$ & 72 & 19, \\
\hline & $\begin{array}{l}\text { 10-19 százalékos } \\
\text { csökkenés }\end{array}$ & 89 & 23, \\
\hline & $\begin{array}{l}<=20 \text { százalékos } \\
\text { csökkenés }\end{array}$ & 14 & 3 , \\
\hline & Együtt & 372 & 100, \\
\hline \multirow{5}{*}{$5000-9999$} & Növekvő & 17 & 77 \\
\hline & Stagnáló +/- 3 százalék & 2 & 9 , \\
\hline & $\begin{array}{l}\text { 4-9 százalékos } \\
\text { csökkenés }\end{array}$ & 2 & 9, \\
\hline & $\begin{array}{l}\text { 10-19 százalékos } \\
\text { csökkenés }\end{array}$ & 1 & 4 \\
\hline & Együtt & 22 & 100, \\
\hline \multirow{2}{*}{$10000-49999$} & Növekvő & 1 & 100, \\
\hline & Együtt & 1 & 100, \\
\hline
\end{tabular}


Együtt 10-19 százalékos 726 26,

csökkenés

csökkenés

Forrás: TEIR adatok alapján saját szerkesztés

\section{A népességdinamikai változások}

Az előbbiekben láthattuk, hogy a községek népességének abszolút száma összességében folyamatosan csökken, azonban ez az adat nem differenciál az egyes települések között. A települések népességváltozásának különbségeit ebben a fejezetben a népességdinamika tipológiáját alkalmazva elemezzük.

A népességdinamika vizsgálatát a Kulcsár, Obádovics (2016) szerzőpáros tipológiájának reprodukciójával végezzük el. A tipológia a településeket a természetes szaporodás (születések száma - halálozások száma) és a vándorlási egyenleg alapján rendezi hat kategóriába, aszerint, hogy az adott település népessége csökkenő, vagy növekvő tendenciát mutat. Mivel elemzésünk fő célja elsősorban a települések népességváltozásának jellemzése, ezért a belföldi és a nemzetközi vándorlást a vándorlási egyenlegbe vontuk össze. A nemzetközi vándorlásban, különösen a magyar állampolgárok külföldre költözésének számbavételében nagy látencia tapasztalható (Gödri 2018). A kivándorlókról vezetett KSH statisztikában csak azokat regisztrálják, akik külföldi letelepedési szándékukat bejelentik, az egyéb, hosszabb-rövidebb ideig külföldön élő magyar állampolgárokról nincsenek adatok. Számukat a fogadó államok tükörstatisztikái alapján lehet becsülni, ami alapján évi 20-30 ezer fó jelenik meg mind a kivándorlási, mind a bevándorlási statisztikákban. A népességdinamika meghatározásához szükséges vándorlási egyenlegbe beépítettük ezeket az adatokat is, bár erősen kérdéses, hogy ezek a számok mennyire fedik le a külföldre irányuló migráció valós mértékét.

A népességdinamika alaptípusainak meghatározása a természetes szaporodás és a vándorlási különbözet összefüggései szerint lehetséges (3. táblázat).

A népességdinamikát meghatározó alapösszefüggések azonban csak arra adnak választ, hogy az adott településen az egyes dimenziókban milyen tendenciák figyelhetők meg, azaz az adott területi egység a vándorlás szempontjából inkább kibocsátó, vagy inkább befogadó területnek számít-e, illetve, hogy miként alakul a természetes szaporodás/fogyás. E megközelítés szerint két „tiszta” kategóriát lehet elkülöníteni: az egyszerre jelenlevő negatív vándorlási különbözet és a természetes fogyás csökkenő népességet eredményez, míg az ellenkező csoportba tartozó településeket növekvő népesség jellemzi. 
3. táblázat: A népességdinamika alaptípusai

Basic types of population dynamics

Természetes szaporodàs Vändorlási külonbozet

\begin{tabular}{lll}
\hline Negatív & $\begin{array}{c}\text { Negatív } \\
\text { Negatív népességdinamika }\end{array}$ & $\begin{array}{l}\text { Pozitív } \\
\text { Pozitív eredményü vándorlás } \\
\text { jelentette népességdinamika }\end{array}$ \\
Pozitív & $\begin{array}{l}\text { Természetes szaporodás } \\
\text { jelentette népességdinamika }\end{array}$ & Pozitív népességdinamika \\
\hline
\end{tabular}

Forrás: Kulcsár, Obádovics 2016

A többi település esetében a természetes szaporodás/fogyás és az oda-és elvándorlás mértéke dönti el, hogy népességvesztő, vagy népességnyerő településről beszélhetünk-e. Így, a természetes szaporodás és a vándorlási különbözet által meghatározott népességszám változásával a tipológia tovább differenciálható. A népességszám-változással meghatározott két (csökkenő, növekvő) főcsoporton belül Kulcsár és Obádovics (2016) három-három alcsoportot alakított ki a természetes szaporodás és a vándorlási különbözet tendenciái szerint (4. táblázat).

4. táblázat: A népességdinamika tipológiája

Typology of population dynamics

\begin{tabular}{ccccc}
$\begin{array}{c}\text { Népességdinamika } \\
\text { fótípusai }\end{array}$ & $\begin{array}{c}\text { Népességdinamika } \\
\text { altípusai }\end{array}$ & $\begin{array}{c}\text { Népességszám } \\
\text { változás }\end{array}$ & $\begin{array}{c}\text { Vándorlási } \\
\text { különbözet }\end{array}$ & $\begin{array}{c}\text { Természetes szaporodás } \\
\text { egyenlege }\end{array}$ \\
\hline \multirow{3}{*}{ 1. Csökkenő } & 1.1 & Csökkenő & Csökkenő & Negatív \\
& 1.2 & Csökkenő & Negatív & Pozitív \\
& 1.3 & Csökkenő & Pozitív & Negatív \\
\hline \multirow{2}{*}{ 2. Növekvő } & 2.1 & Növekvő & Növekvő & Negatív \\
& 2.2 & Növekvő & Pozitív & Negatív \\
& 2.3 & Növekvő & Pozitív & Pozitív \\
\hline
\end{tabular}

Forrás: Kulcsár, Obádovics 2016

2006-ot követően minden évben sokkal több a csökkenő, mint a növekvő lakosságszámú község. A különbség több évben kétszeres vagy ennél is magasabb (6. ábra). Az összetett változásokat árnyaltabban bemutató népességdinamika mutató szerint a községek több mint harmada évről évre a teljes mértékben csökkenő kategóriához tartozik, míg a növekvő községek aránya 10 százalék körül mozog (2. melléklet).

A községek népességdinamika szerinti megoszlásának országos mintázatát mutatja a 7. ábra. A növekvő népességű települések a főváros körül és Győr-Moson-Sopron megyében vannak többségben, ezen kívül a Balaton környékén, a Duna-Tisza közén, és kisebb foltokban a Dél-Dunántúlon fordulnak még elő. Az ország többi részén, különösen Észak-Magyarországon és a Dél-Dunántúlon a túlnyomó többséget a népességvesztő falvak adják. 
6. ábra: A változatlan közigazgatási besorolású községek a népességváltozás

kategóriái szerint 2006 és 2016 között

Settlements with unchanged administrative classification by

categories of population change between 2006 and 2016

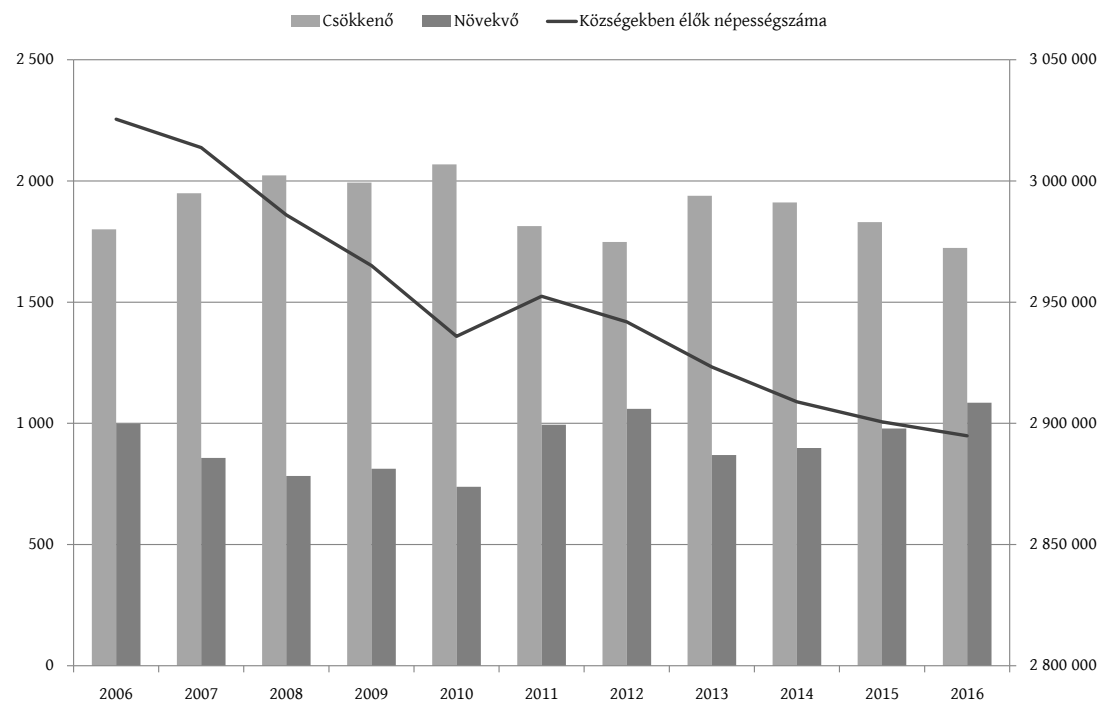

Forrás: TEIR, KSH adatok alapján saját szerkesztés

7. ábra: A községek népességdinamikája, 2016

Population dynamics of villages, 2016

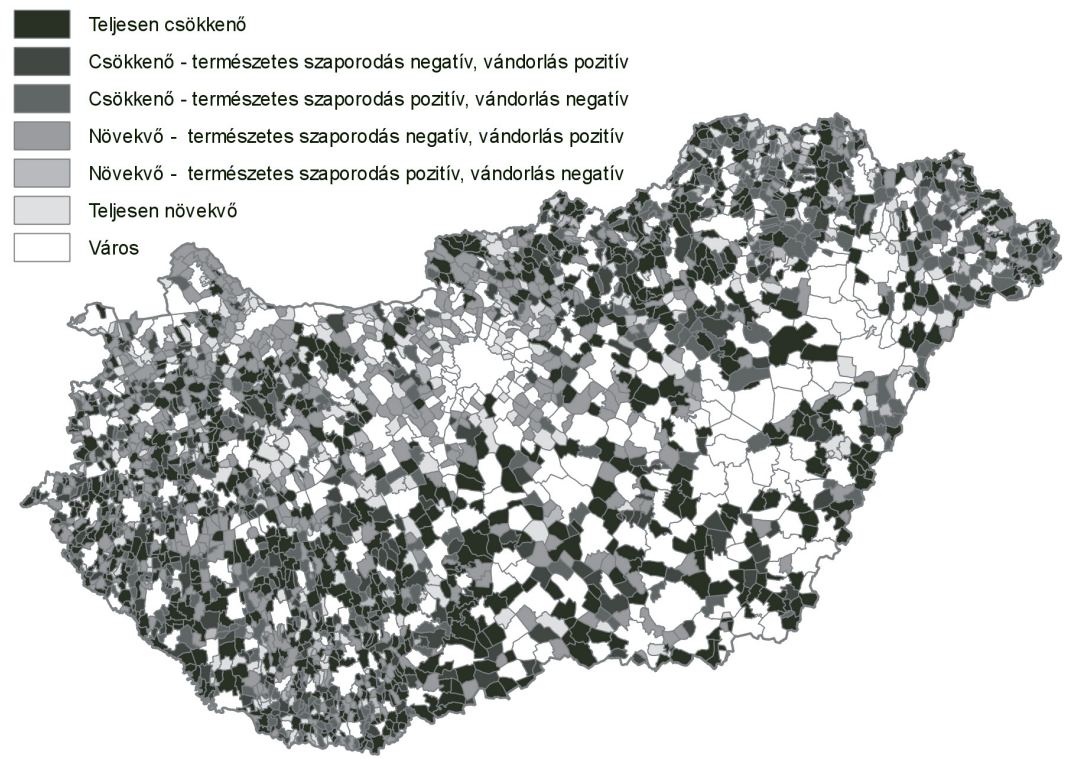

Forrás: TEIR, KSH adatok a lapján saját szerkesztés 


\section{A községek vándorlási egyenlege és a települések fejlettsége}

A települések fejlettségének meghatározásáról könyvtárnyi irodalom áll rendelkezésre. E kutatások célja elsősorban az, hogy a fejlesztéspolitika számára láthatóvá tegye a hátrányos helyzetű térségeket. A kutatók igyekeznek megtalálni azokat az indikátorokat, amelyek meghatározzák a települések fejlettségét, és egy olyan komplex változóba sűríthetők, amely a legteljesebb módon képes kifejezni a fejlettséget (Harcsa 2015; Pénzes 2015; Papp 2018).

Magyarországon az 1970-es években indult meg az elmaradott térségek átfogó tudományos vizsgálata. A különböző mérőeszközök egyaránt igyekeznek vizsgálni a gazdasági fejlettséget, az infrastruktúrát és a demográfiai szempontokat (Pénzes 2015), amelyek összehasonlítása külön tanulmányokat tesz ki (Nagy 2012; Harcsa 2015; Pénzes 2015; Papp 2018), éppen ezért ebben az elemzésben eltekintünk a különböző módon mért területi fejlettség részletes bemutatásától. A hivatkozott tanulmányokból kitűnik, hogy bár az egyes fejlettségi mutatók módszertana eltérő, többnyire ugyanarra az eredményre jutnak, és közel azonos az a települési kör, amelyet hátrányos helyzetűként azonosítanak.

A továbbiakban a 105/2015 kormányrendeletben meghatározott - a KSH által kialakított - települési komplex fejlettségi mutatót használjuk a községek fejlettségének megállapításához. A rendelet a komplex mutatót képező változókat négy csoportra bontja: 1) társadalmi és demográfiai helyzet, 2) lakás- és életkörülmények, 3) helyi gazdaság és munkaerőpiac, 4) infrastruktúra és környezet. A KSH egyedi adatkérés alapján rendelkezésünkre bocsátotta a szükséges változókat a 2015-ös évre vonatkozóan, így a rendeletben leírt módszertant követve magunk készítettük el a fejlettségi mutatót.

Az elemzés kérdése most az, hogy a települések különböző szempontú fejlettsége miként befolyásolja a belföldi vándorlást. Éppen ezért a települési fejlettséget nem a teljes komplex mutatóval határoztuk meg, hanem csupán a csoportindikátorokat készítettük el és vetettük össze a vándorlási egyenleggel. Ennek oka, hogy a komplex mutató egyik eleme a demográfiai változócsoport miatt maga a belföldi vándorlási egyenleg, éppen ezért a fejlettség meghatározásához csak a gazdasági fejlettséget, az életkörülményeket és az infrastrukturális fejlettséget vesszük alapul. A változók értékeit úgy módosítottuk, hogy mindegyik változó esetében a magas érték jelentse a fejlettséget, majd a rendeletben leírt képlet szerint normalizáltuk őket, és ugyancsak a rendelet alapján készítettük el a csoportindikátorokat. A nagyobb érték nagyobb fejlettséget jelent.

Annak érdekében, hogy érzékeltethessük az egyes csoportindikátorok szerinti fejlettség országos szintjét, a községeket mindegyik dimenzió mentén három csoportba soroltuk: 1) hátrányos helyzetű települések, 2) átlagos települések, 3) fejlett települések. A csoportosításhoz csak a községek indexértékeit vettük figyelembe. A besoroláshoz a települések alsó és felső 1\%-át kihagytuk, mivel azok outlier érté- 
8. ábra: A változatlan közigazgatási besorolású községek fejlettsége

a helyi gazdaság és munkaerőpiac szerint

The development level of villages with unchanged administrative

classification by the local economy and labor market

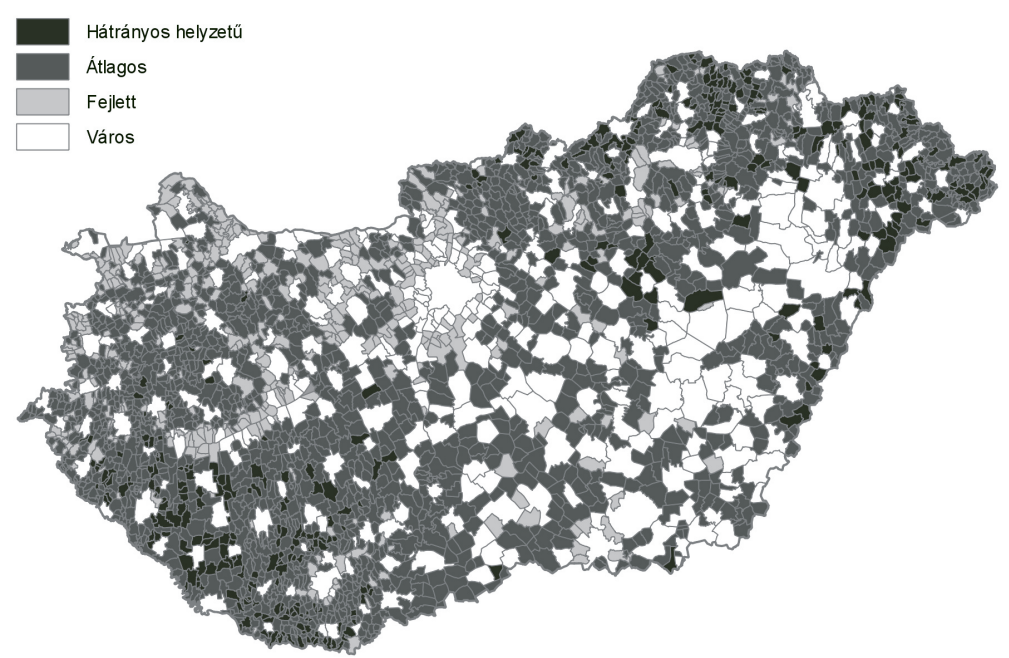

Forrás: KSH adatok alapján saját szerkesztés

ket jelentettek, majd az indexértékek terjedelme alapján alakítottuk ki a három csoportot. A községek fejlettség szerinti megoszlása a 8-10. ábrán látható.

9. ábra: A változatlan közigazgatási besorolású községek fejlettsége az infrastruktúra és a környezet szerint

The development level of villages with unchanged administrative classification by the infrastructure and the environment

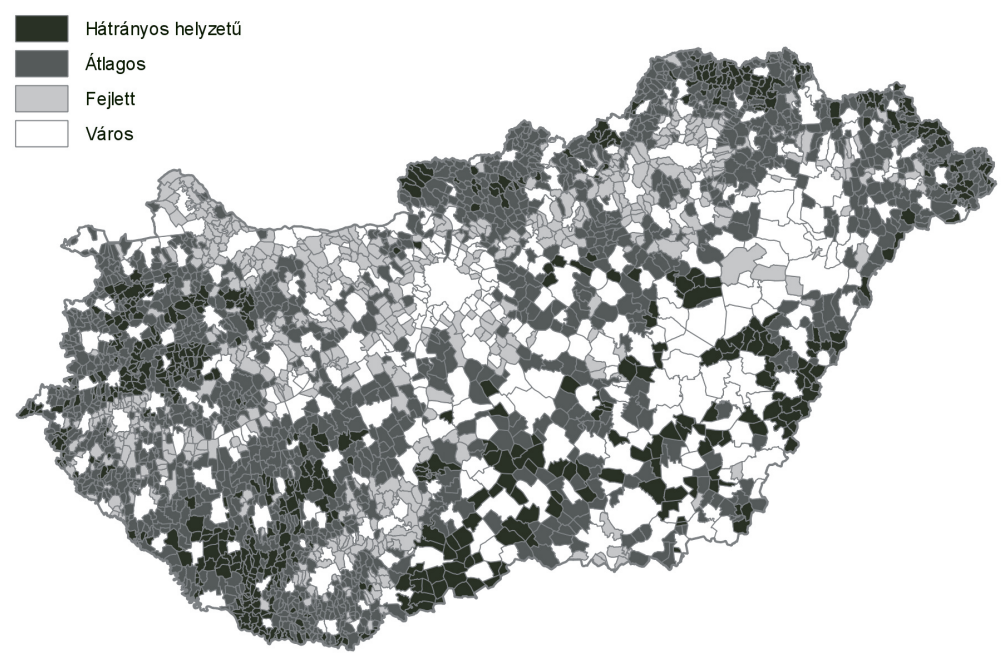

Forrás: KSH adatok alapján saját szerkesztés 
10. ábra: A változatlan közigazgatási besorolású községek fejlettsége a lakás- és az életkörülmények szerint

The development level of villages with unchanged administrative classification by the housing and the living conditions

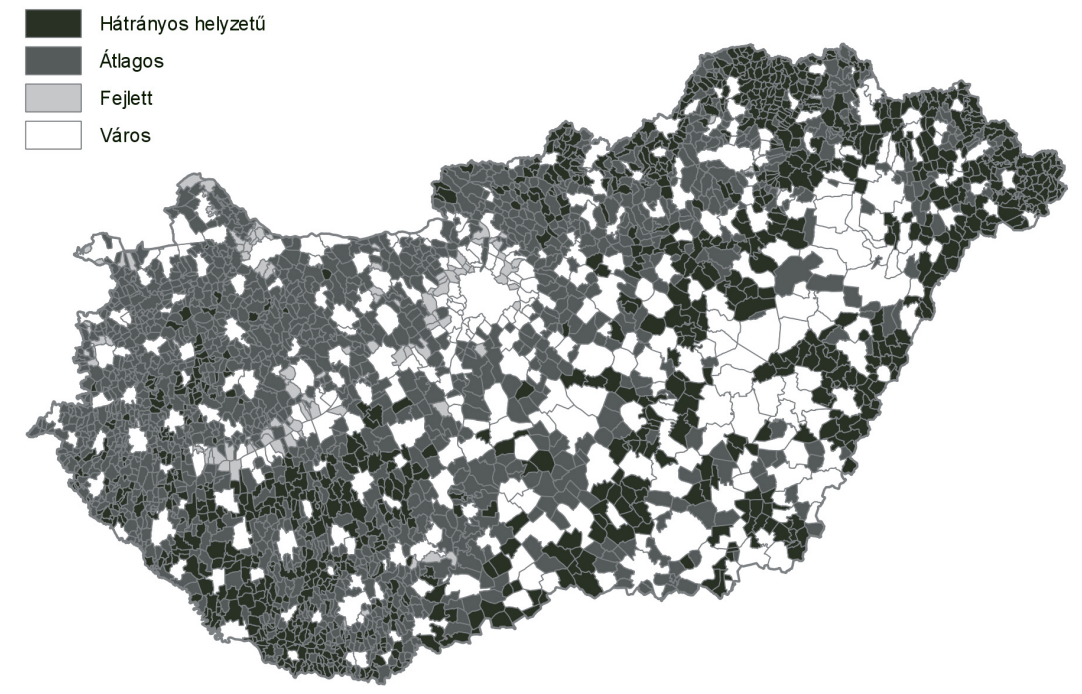

Forrás: KSH adatok alapján saját szerkesztés

A leghátrányosabb helyzetű települések Észak-Magyarországon és a Dél-Dunántúlon találhatók, hiszen ezekben a térségekben mindegyik csoportindikátor hátrányos helyzetű településeket jelez. Budapest környéke és az Észak- NyugatDunántúl gazdaságilag és infrastrukturálisan is fejlett, szembetűnő azonban, hogy ezek a részek is legfeljebb átlagos fejlettséget mutatnak a lakás-és életkörülmények szempontjából, míg az ország kétharmada hátrányos helyzetűnek számít e dimenzió szerint.

A településeket a vándorlási egyenleget mutató térkép (11. ábra) elkészítéséhez is három kategóriába soroltuk úgy, hogy a kiegyenlített kategóriába a 0 és a +/- 5 fő vándorlási egyenlegü települések tartoznak. Bár minden régióban inkább a vándorlási szempontból népességvesztő települések a jellemzőek, a térképek mintázatainak összevetésével jól látható, hogy természetszerűen milyen gazdaságilag és infrastrukturálisan fejlett kategóriába tartozó települések vonzóak a belföldi vándorlás szempontjából.

A továbbiakban annak vizsgálatára tettünk kísérletet, hogy a három fejlettségi dimenzió szerint mért települési fejlettség hogyan befolyásolja a vándorlási egyenleget. Ennek a becséléshez többváltozós logisztikus regressziós modellt készítettünk. Korlátot jelent, hogy a fejlettséget mérő változókat a KSH csak a 2015-ös évről bocsátotta a rendelkezésünkre, így a modellt csak erre az évre vonatkozóan tudtuk elkészíteni. A vizsgált települések körét itt is a mindig a falvak jelentik. 
11. ábra: A változatlan közigazgatási besorolású községek megoszlása vándorlási egyenlegük szerint

Villages with unchanged administrative classification by their migration balance scale

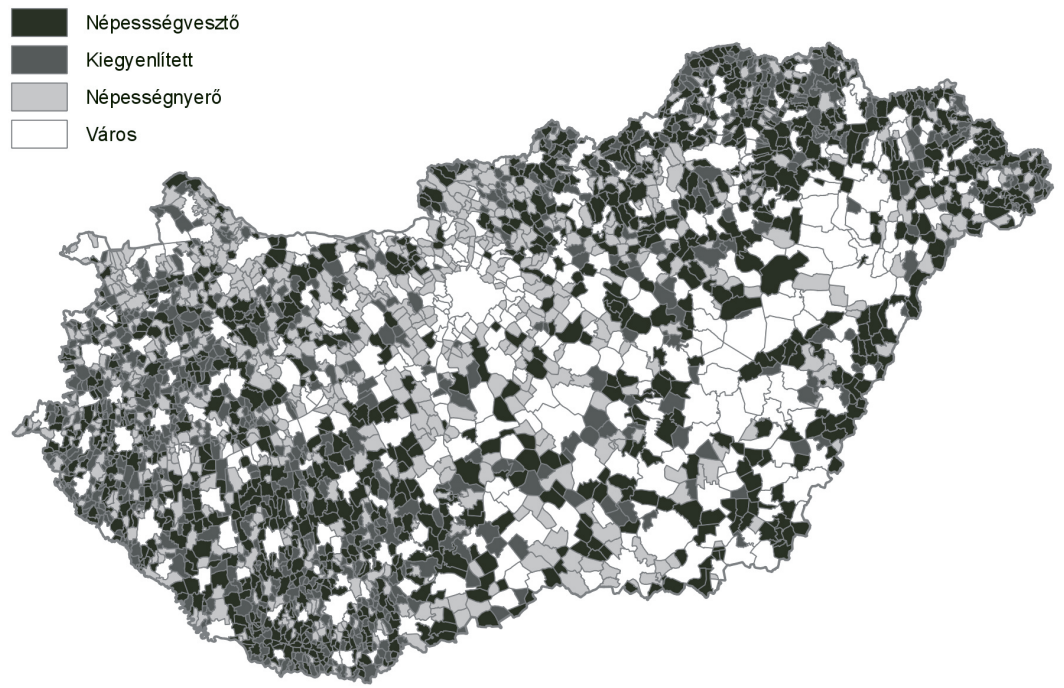

Forrás: KSH adatok alapján saját szerkesztés

Modellünk függő változóját a vándorlási egyenleg dichotóm formájúvá transzformált alakja jelenti, azaz, hogy az adott település pozitív vándorlási egyenleggel rendelkezik-e. A fejlettség mértékét a három dimenzió szerinti fejlettségi index értékével mértük, ${ }^{6}$ kontrollváltozóként pedig a település népességszámát, a természetes szaporodás egyenlegét és a nagyrégiót vontuk be, így kiszürve a térbeli elhelyezkedés és népességnagyság hatását (5. táblázat).

5. táblázat: A települési fejlettség hatása a vándorlásra - alap és bővített modell - Függő változó: Vándorlási egyenleg pozitív-e (1=igen)

The impact of settlement development on migration - basic and extended model - Dependent variable: Is the migration balance scale positive? ( $1=$ yes)

IMloaell(L)

\begin{tabular}{|c|c|c|c|c|}
\hline & B & $\operatorname{Exp}(B)$ & B & $\operatorname{Exp}(B)$ \\
\hline Lakás- és életkörülmények & 0,060 & $1,061^{* * *}$ & 0,062 & $1,064^{* * *}$ \\
\hline Helyi gazdaság és munkaerőpiac & 0,014 & 1,014 & 0,001 & 1,001 \\
\hline Infrastruktúra és környezet & 0,016 & $1,017^{* * *}$ & 0,012 & $1,012^{* *}$ \\
\hline Kontroll változók & \multicolumn{2}{|c|}{ nem } & \multicolumn{2}{|c|}{ igen } \\
\hline Konstans & $-4,247$ & 0,014 & $-3,098$ & 0,045 \\
\hline $\mathrm{N}$ & \multicolumn{2}{|c|}{2808} & \multicolumn{2}{|c|}{2808} \\
\hline $\mathrm{R}_{\mathrm{L}}^{2}$ & \multicolumn{2}{|c|}{0,060} & \multicolumn{2}{|c|}{0,090} \\
\hline
\end{tabular}

Megjegyzés: ${ }^{* * *} p<0,001 ; * * 0,01 ;{ }^{*} p<0,05$

Kontroll változók: település népességszáma, természetes szaporodás egyenlege, nagyrégiók Forrás: KSH, TEIR adatok alapján saját szerkesztés 
Nem meglepő, hogy a magasabb települési fejlettség növeli annak az esélyét, hogy a település pozitív vándorlási egyenleggel rendelkezzen, ugyanakkor kiemeleten fontos figyelembe venni az egyes fejlettségi dimenziók hatása közötti eltérést. A vándorlási egyenleget a lakás- és életkörülmények szignifikánsan befolyásolják, amely korszerübb, újabb, drágább lakásállományt, illetve magasabb életszínvonalat jelent, hiszen ezeken a céltelepüléseken magasabb az egy állandó lakosra jutó SZJA alapot képző jövedelem, illetve magasabb a természetes személyek által üzemeltetett autók kor szerint súlyozott ezer lakosra jutó száma. Szintén szignifikáns hatása van az infrastrukturális fejlettségnek, így a megfelelően kiépített úthálózat, a megyeszékhelyek vagy gyorsforgalmi csomópontok közelsége, illetve a közüzemi szolgáltatások kiépítettsége (szennyvízelvezetés, rendszeres hulladékgyüjtés) növeli az odavándorlás esélyét. A helyi gazdaság és a munkaerőpiac ugyanakkor nem hat szignifikánsan a vándorlási egyenlegre. A helyben müködő vállalkozások és kiskereskedelmi üzletek kevésbé vonzóak, mint a városok gyors elérhetősége. Ezen összefüggések jobb megértéshez további részletes elemzések szükségesek.

\section{Összegzés}

Arra vállalkoztunk, hogy a hozzáférhető legfrissebb (2016-os) adatok alapján áttekintést készítsünk a községek népességszámának változásáról. Az elemzések első részében a népesség abszolút adatait vizsgáltuk, majd a változatlan közigazgatási besorolású községek adatait elemeztük. A vándorlási majd a népességdinamikai számítások összetett módszerei, és a más településkategóriákhoz viszonyított mutatók szerint tanulmányoztuk a községek népességváltozását, majd a vándorlási adatokat és a települések fejlettségi indexeit vetettük össze.

A községek népességének csökkenése folyamatos volt 1995-2016 között, amelyet a legerősebben 152 község várossá nyilvánítása befolyásolt. A falusi népesség veszteségének döntő része az új városok közigazgatási besorolásának változásából ered. Az új városok népességszáma Budapest vonzáskörzetében nőtt, míg más régiókban az új városi rang ellenére csökkent a lakosság. Mivel az új városok legalább fele központhiányos, a falusi életmódminták átalakulása hosszú időtartamú, és mert az ország teljes lakossága is jelentősen csökkent, nem állítható, hogy a magyar társadalomban a községek egymillió főhöz közeli népességvesztése alapvetően változtatott volna a vidékiek arányán, ami sokkal magasabb, mint a 2004 előtti EU-tagállamok átlaga. Az egyes településkategóriák között korántsem a változatlan közigazgatási besorolású községek népességvesztesége százalékosan a legnagyobb.

A szakirodalom szerint a népesség számának változása egyre inkább az odaés elvándorlások egyensúlyától függ. A KSH vándorlási adatai szerint 1995 és 2005 között a falvakban pozitív volt a vándorlási különbözet. Azt követően csökkent a pozitív vándorlási egyenleg, majd 2006 és 2012 között erősen negatívvá 
változott, a 2013 és 2016 közötti években pedig lényegében stagnált. A községeket érintő vándorlás irányai és nagysága többször változtak 1990 után, és az egyes korszakok értékelése nem egyszerü feladat. Az 1995 és 2005 közötti bevándorlási időszak egyfelől növelte a községek lakosságát, másrészt hozzájárult a községek közötti egyenlőtlenségek elmélyüléséhez. A bevándorlás a kedvezőtlen helyzetü falvakban a leszakadó társadalmi csoportok arányát növelte meg, míg a zömében nagyvárosi agglomerációkba sokkal több aktív és magasabb társadalmi tőkével rendelkező telepedett. A községekből az el- és odavándorlások száma együttesen éves szintes 300000 - 400000 között mozog, ami a belső vándorlás országos adatainak a harmada, tehát valamivel magasabb arány, mint a községek részesedése a teljes a magyar népességen belül. Ebből az adatból egyrészt az következik, hogy a falusi helyi társadalmak korántsem zárt közösségek, másrészt ilyen nagyságrendű népességmozgás jelentős és folyamatos társadalmi átrétegződéshez vezet. Ennek összes következményét nem lehet a rendelkezésre álló vándorlási és demográfiai statisztikák alapján kimutatni, mindehhez összetettebb adatfelvétel szükséges.

Egyértelmű azonban, hogy míg a változatlan közigazgatási besorolású községek népességszáma viszonylag stabil volt 20 év alatt, alig három százalékos lakosságveszteséggel, addig a népesség nagysága szerinti faluosztályok között jelentős elmozdulások történtek. Az 1000 fó, és főleg az 500 fö alatti falvak lakossága gyorsan fogy, öregszik, szegényedik és a nagyobb községekbe költözik, különösen a nagyvárosi agglomerációkba, ahol a városi kitelepedés is hozzájárul a népességszám emelkedéséhez. A városkörnyéki és távoli falvak között már korábban is kimutatott radikális differenciálódás (Kovách 2012) az utóbbi években is folytatódott, illetve a különbségek mintegy megmerevedtek, és alig változnak.

Az összetett változások (vándorlás, természetes szaporodás/csökkenés) mérésére alkalmas népességdinamikai módszer szerint 574 községben nőtt a népesség száma, 1638 községben átlagosan, vagy csak kisebb arányban csökkent a népesség, és 614 település népessége csökkent nagyobb mértékben. A lakás-és életkörülmények szerint, ami a vándorlás legfőbb motiválója, a községek kétharmada hátrányos helyzetű, és ez valószínűsítheti a népességcsökkenés felgyorsulását az alacsonyabb lélekszámú falvakban, falusi régiókban, ahonnan fokozódhat az áttelepülés a nagyközségekbe, új városokba. Mindez minőségi változást is magával hozhat: miközben a községi népesség, és a nagyon lassan és felemásan urbanizálódó legújabb és nemrégi kisvárosokkal együtt számítva a vidéki népesség tartósan a magyar társadalom felét is adhatja, addig a hagyományos parasztság eltűnése után a régmúlt idilli falvai helyébe egészen más szerkezetű és összetételű vidéki településminőség kerülhet. 


\section{Jegyzet}

1 Vagy valamilyen más szempont szerint kiválasztott év.

2 Azaz, amelyek 1995 és 2016 között mindig község besorolással rendelkeztek.

3 https://www.teir.hu/

4 A létrejövő longitudinális adatbázisban a sorokat az évszámból és a településkódból képzett azonosító teszi egyedivé.

5 A vándorlási statisztikával kapcsolatban fontos megjegyezni, hogy az adatok forrása a lakcímbejelentési rendszer, amelyről a Belügyminisztérium Nyilvántartások Vezetéséért Felelős Helyettes Államtitkárság (BM NYHÁT, korábban KEKKH) szolgáltat adatállományokat a KSH-nak statisztikai feldolgozás céljára. A lakcímbejelentési rendszer alapján pedig nem a vándorlók, hanem az adott évben bekövetkező vándorlások esetszámát ismerjük, tehát ha valaki egy éven belül változtat lakóhelyet, többször jelenik meg a statisztikában. (KSH-STADAT módszertan, http://www.ksh.hu/docs/hun/modsz/modsz10.html, utolsó letöltés: 2020.04.02.; Gödri, Spéder (2009).

6 A fejlettségi dimenziók csoportindikátorainak használata korlátot jelent. Ugyanis egy-egy település fejlettsége még sok más változóval is mérhető, s bár a csoportindikátorok megalkotására számos elméleti megfontolást és empirikus tesztelést követően került sor, nem elképzelhetetlen, hogy valamely változó helyettesíthető lenne más alkalmas változóval is, amely jelentős változást idézne elő az eredményeinkben. Ugyanakkor egyes szakirodalmi források alapján (lásd Pénzes 2015) elfogadjuk, hogy a kormányrendeletben meghatározott fejlettségi indikátorok valid, és a meghatározott dimenziót lefedni képes fejlettségi mutatók.

\section{Köszönetnyilvánítás}

A tanulmány létrejöttét a NKFI 128965 számú kutatási programja támogatta. A szerzők ezúton szeretnének köszönetet mondani Csurgó Bernadettnek, Győri Ágnesnek, Harcsa Istvánnak és Spéder Zsoltnak, akik szakmai észrevételeikkel segítették a tanulmány elkészítését.

\section{Irodalom}

Alston, M. (2004): “You don”t want to be a check-out chick all your life": the out-migration of young people from Australia's small rural towns. Australian Journal of Social Issues, 3., 299-313. https://doi.org/10.1002/j.1839-4655.2004.tb01178.x.

Bálint L., Gödri I. (2015): Belföldi vándorlás. In: Monostori J., Őri P., Spéder Zs. (szerk.): Demográfiai Portré 2015. KSH Népességtudományi Kutatóintézet, Budapest, 171-185.

Bálint L., Obádovics Cs. (2018): Belföldi vándorlás. In: Monostori J., Őri P., Spéder Zs. (szerk.): Demográfiai Portré 2018. KSH Népességtudományi Kutatóintézet, Budapest, 217-236.

Bálint L. (2012): Belföldi vándorlás 2012. In: Őri P., Spéder Zs,. (szerk.): Demográfiai Portré 2012. KSH Népességtudományi Kutatóintézet, Budapest, 126-136.

Boyle, P., Halfacree, K. (1998): Migration into rural areas: theories and issues. John Wiley \& Sons, Chicheste

Boyle, P., Halfacree, K. (2014): Exploring contemporary migration. Routledge, London

Brown, D. L., Champion, T., Coombes, M., Wymer, C. (2015): The Migration-commuting nexus: migration and commuting in rural England, 2002-2006: A longitudinal analysis. Journal of Rural Studies, 31., 118-128. http://dx.doi.org/10.1016/j 
Callea, S. (1986): Different forms, reasons and motivations for return migration of persons who voluntarily decide to return to their countries of origin. International Migration, 1., 61-76. https://doi.org/ 10.1111/j.1468-2435.1986.tb00102.x.

Czibere I., Kovách I. (2019): Községekben élő immobil fiatalok. Metszetek. Társadalomtudományi folyóirat, 3., 3-22. https://doi.org/ 10.18392/metsz/2019/3/1

Csatári B. (2004): A magyarországi vidékiségről, annak kritériumairól és krízisjelenségeiről. Területi Statisztika, 6., 532-543.

Csatári B. (2007): Tények az európai és magyar vidékekről 2000 táján. In: Kovács T. (szerk.): A vidéki Magyarország az EU-csatlakozás után. MTA RKK, Pécs, 59-68.

Dövényi Z. (2007): A belföldi vándormozgalom strukturális és területi sajátosságai Magyarországon. Demográfia, 4., 335-359.

Dövényi Z. (2009): A belső vándormozgalom Magyarországon: folyamatok és struktúrák. Statisztikai Szemle, 7-8., 748-762.

Gerse J.,Szilágyi D. (2015): Magyarország településhálózata 2. KSH, Budapest

Gödri I., Spéder Zs. (2009): Belföldi vándorlás. In: Monostori J., Őri P., S. Molnár E., Spéder Zs. (szerk.): Demográfiai Portré 2009. KSH Népességtudományi Kutatóintézet, Budapest, 109-117.

Gödri I. (2018): Nemzetközi vándorlás. In: Monostori J., Őri P., Spéder. Zs. (szerk.): Demográfiai Portré 2018. KSH Népességtudományi Kutatóintézet, Budapest, 237-270.

Harcsa I. (2015): A területi fejlettség és egyenlőtlenségek lehetséges értelmezései - kritikai értékelés és kutatási eredmények I., Statisztikai Szemle, 5., 460-486.

Horzsa G. (2018): A fejlesztési környezet szerepe a belső vándorlás alakulásában. socio.hu, 3., 25-41. https://doi.org/10.18030/socio.hu.2018.3.25

Kovách I., Megyesi B. (2018): A vidék harminc éve. A magyar vidék alakulása az erőforrások, a társadalmi tőke és fejlesztéspolitikai változásainak tükrében. Erdélyi Társadalom, 1., 83-104.

Kovách I. (2012): A vidék az ezredfordulón: A jelenkori magyar vidéki társadalom szerkezeti és hatalmi változásai. Argumentum Kiadó, Budapest

KSH (2012): A belföldi vándorlás fóbb folyamatai, 1990-2011. Statisztikai Tükör, 85.

KSH (2018): A belföldi vándorlás aktuális trendjei, 2012-2017.

Kulcsár L. Obádovics Cs. (2016): Népességdinamika és társadalmi szerkezet. Területi Statisztika, 4., 390-414.

Kulcsár L. (2017): A vidékfejlesztés elméleti megközelitése. Kriterion Könyvkiadó, Pro Ruralis Egyesület, Kolozsvár

Kulcsár, L, J., Brown, D.L. (2010): The Political Economy of Urban Reclassification in Post-Socialist Hungary. Regional Studies, 4., 479-490. https://doi.org/10.180/00343400903496378

Leibert, T. (2016) She leaves, he stays? Sex-selective migration in rural East Germany. Journal of Rural Studies, 43., 267-279. DOI:10.1016/j.jrurstud.2015.06.004

Nagy A. (2011): A kedvezményezett térségek besorolásának alakulása, a lehatárolások módszertanának sajátosságai. Területi Statisztika, 2., 148-160.

Németh Á., Dövényi Z. (2016): Magyarország településeinek népesedési típusai (1970-2011). In: Pajtókné Tari I., Tóth A. (szerk.): Magyar Földrajzi Napok 2016. Konferenciakötet. VIII. Magyar Földrajzi Konferencia, XVI. Geográfus Doktoranduszok Országos Konferenciája, Oktatásmódszertani és Földrajztanári Konferencia, Eger, 301-311.

Németh Zs. (2008): A megyék társadalomszerkezete és a vándorlások. Demográfia, 1-2., 181-216.

Papp S. (2018): A hátrányos helyzetű területek lehatárolásának lehetőségei. In: Rózsa K. (szerk.): Eötvözet VI.: Az Eötvös József Collegium és az Eötvös Loránd Kollégium VI. közös konferenciáján elhangzott előadások. SZTE Eötvös Loránd Kollégium, Szeged, 149-160.

Pénzes J. (2015): A kedvezményezett térségek lehatárolásának aktuális kérdései. Területi Statisztika, 3., 206-232.

Pirisi G. (2009): Város vagy nem város? Dilemmák a formális és a funkcionális városfogalom kettőssége kapcsán. Területi Statisztika, 2., 129-136.

Pirisi G., Trócsányi A. (2009): Így készül a magyar város. Területi Statisztika 2., 137-147.

Schmied, D. (2002): Winning and Losing. The changing geography of Europe's rural areas. Aldershot, Ashgate 
Scott, M., Murphy, E., Gkartzios, M. (2017): Placing 'Home' and 'Family' in rural residential mobilities. Sociologia Ruralis, 57., 598-621. https://doi.org/10.111/soru.12165

Solana-Solana, M. (2010): Rural gentrification in Catalonia, Spain: A case study of migration, social change and conflicts in the Empordanet area. Geoforum, 3., 508-517. DOI:10.1016/j.geoforum. 2010.01.005

Stockdale, A. (2002): Towards a typology of out-migration from peripheral areas: a Scottish case study. International Journal of Population Geography, 8., 345-364. https://doi.org/10.1002/ijpg.265

Trócsányi A., Pirisi G., Malatyinszki Sz. (2007): A célnál fontosabb a bejárt út. A várossá nyilvánítás gyakorlata Magyarországon. Falu Város Régió 3., 18-27.

Thissen, F., Fortuijn, J. D., Strijker, D., Haartsen, T. (2010): Migration intentions of rural youth in the Westhoek, Flanders, Belgium and the Veenkoloniën, The Netherlands. Journal of Rural Studies, 4., 428-436. https://doi.org/10.1016/jrurstud.2010.05.001

\section{Melléklet}

1. sz. melléklet: Az 1995-2016 között várossá nyilvánított települések népesség számának a változása

Population change of the settlements whose administrative classification changed from village to city between 1995 and 2016

\begin{tabular}{ccc} 
Év & A településekszáma & $\begin{array}{c}\text { A népesség száma } \\
\text { azév végén }\end{array}$ \\
\hline 1995 & 152 & 846044 \\
1996 & 152 & 849517 \\
1997 & 152 & 854775 \\
1998 & 152 & 859433 \\
1999 & 152 & 864207 \\
2000 & 152 & 889889 \\
2001 & 152 & 898001 \\
2002 & 152 & 904588 \\
2003 & 152 & 911997 \\
2004 & 152 & 919128 \\
2005 & 152 & 922864 \\
2006 & 152 & 928613 \\
2007 & 152 & 933716 \\
2008 & 152 & 936594 \\
2009 & 152 & 940481 \\
2010 & 152 & 938548 \\
2011 & 152 & 935374 \\
2012 & 152 & 935672 \\
2013 & 152 & 934398 \\
2014 & 152 & 934226 \\
2015 & 152 & 934353 \\
2016 & 152 & 938670 \\
\hline
\end{tabular}

Forrás: KSH, TEIR adatok alapján saját szerkesztés 


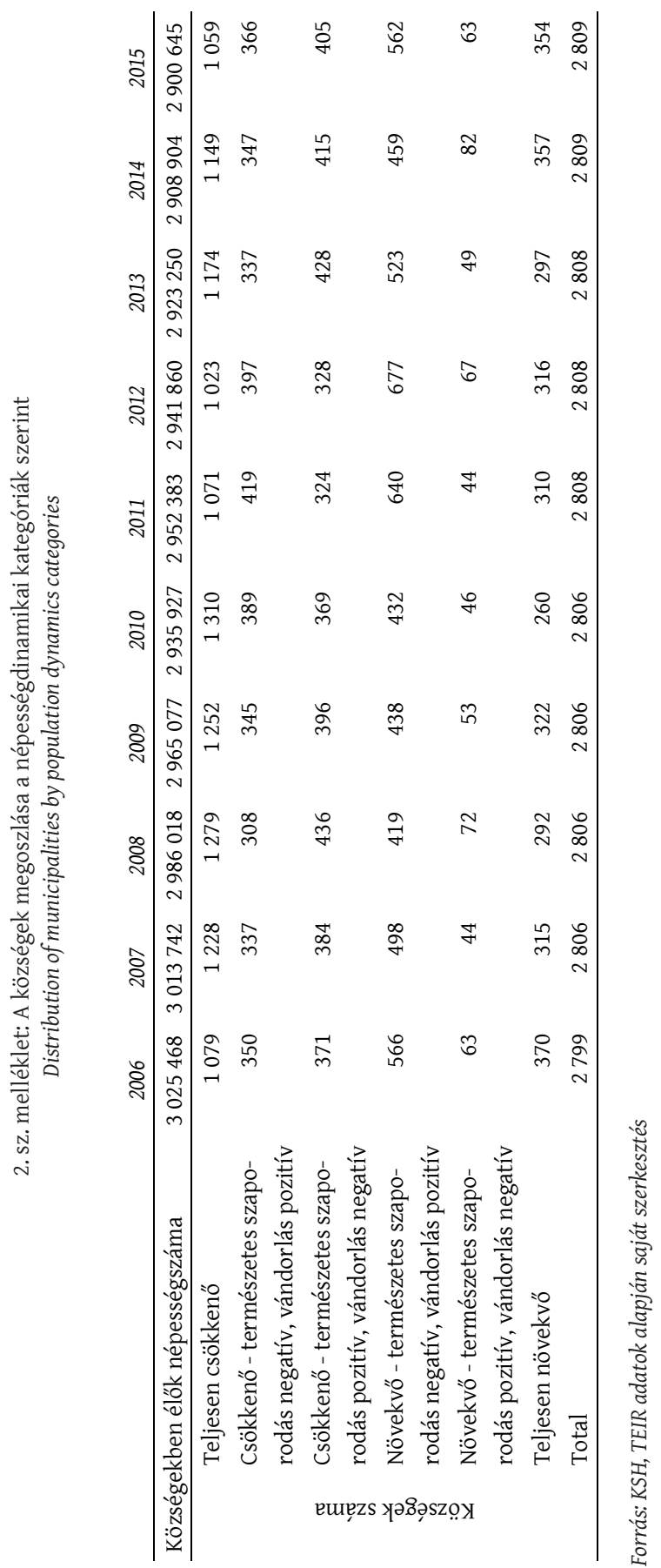

